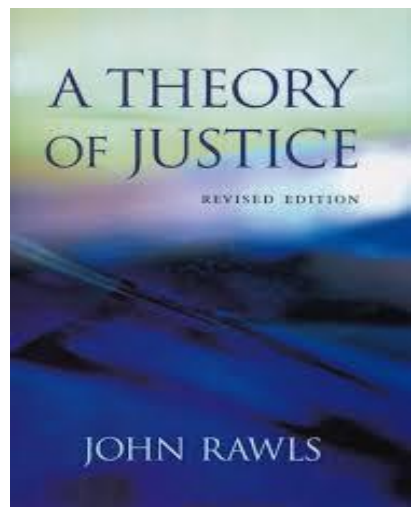

Rawls, J. (1999). A Theory of Justice: Revised Edition. Harvard University Press. 560 pp., ISBN:0-674-00078-1

\title{
Rawls's Theory of Justice and its Relevance in Analyzing Injustice on Ethnic Phenomenon
}

\author{
Cut Maya Aprita Sari ${ }^{1}$ \\ Universitas Syiah Kuala, Aceh - Indonesia
}

John Rawls was an American political philosopher who had liberal views. Rawls was born in 1921 and grew up in Baltimore, Maryland. His father was a renowned lawyer, while his mother was a chapter president for League of Women Voters. He studied at Princeton University. His political thinking was influenced by Wittgenstein, an Austrian-British philosopher, who was also a student of Norman Malcolm.

Rawls then worked in Oxford University and was inaugurated as a professor at Cornell and MIT. In 1962, Rawls joined Harvard University and taught for more than thirty years before he died in 2002. Some of his best-known works are, A Theory of Justice (1971 \& 1999), Political Liberalism (1993), The Law of People (1999) and Justice as Fairness (2001).

A Theory of Justice was initially published in 1971 and then revised in 1999. This book discussed the justices theories that are usually utilitarianism in nature and that were developing in the West. Rawls tried to develop several base ideas in the social contract traditions and offered alternative thinking in the form of anti-utilitarian philosophy (p. 14) Rawls continued social contract traditions that were pioneered by Locke, Hobbes, and Roseau. In his era, A Theory of Justice book became the leading treatise that talked about political philosophy and also became the primary reference regarding social philosophy. In general, this book describes the theories of justice and their applications in social life. Every theory, as well as the principles described in this book, can be applied by both institutions and society so that social justice can be realized.

This book was divided into three parts, and each part contained three chapters. The first part, titled "Theory," elaborated on justice theories and explained that they were Justice as Fairness, The Principle of Justice and The Original Position. The second part, titled "Institution," explained the application of those justice theories within institutions and was divided into three sections, they were Equal Liberty, Distributive Shares and Duty, and Obligation. In the third part, titled, "Ends," Rawls finally explained general theories that aim to clarify the relationship between justice and fairness with social justice values. This last part had three sections, which were Goodness as Rationality, The Sense of Justice, and The Good of Justice.

${ }^{1}$ Correspondent Author E-Mail: cutmayaapritasari@unsyiah.ac.id 
This book is very suitable to be read by the people who are concerned with issues of distributive justice, social democracy, and social justice, especially political scientists and experts in constitutional law. Researchers often used the theory of justice that John Rawls explicated in a limited way and only to explain the problem of economic inequality, which, in turn, raises conflicts in society. The theory of justice that Rawls proposed is very complex and comprehensive. The theory is not only able to explain injustice in an economic context, but Rawls' justice theory is significant for analyzing problems that are related to ethnicity, especially about ethnic discrimination. By using a qualitative method based on a literature review, this paper reviews and explore Rawls' theory of justice and its relevance in analyzing injustice related to ethnic phenomena. Finally, this paper also provides the recommendations for researchers who are concerned with the issue of ethnic conflict to be able to use Rawls' theory of justice as an alternative analysis tool for explaining injustice in ethnic issues.

\section{A Theory of Justice, Review and Discussion}

In explaining his opinions about the theory of justice, Rawls sectioned his book on three main parts. Part one titled "Theory" is divided into three related chapters. Chapter I "Justice as Fairness"; Chapter II "The Principle of Justice," and Chapter III "The Original Position." Rawls started Part One of his book, which is titled "Theory," with basic questions. Rawls began by asking a question: "If everyone loses their privileges and social status, what sort of justice system would they want?" Rawls then gave a logical choice, which was a system that treated people equally regardless of their race, class, gender and other personal aspects. The utilitarian argument contended that society must strive for the greater good to achieve more generous amounts of good as well. This result is challenging to achieve, especially for societies whose social structure is consistent with the tyranny of the majority. Therefore, Rawls (p. 19-24) formulated social justice with the foundations based on the social contract approach. This approach stated that the existence of a society is the result of unanimous decision between those societies and their peoples to create a social contract agreement. Rawls then asked, what is the content of that social contract agreement? And what rules and regulations must everyone agree upon?

To answer those questions, Rawls continued by formulating theories that he named "Justice as Fairness" that are explained in chapter I of this book (p. 3-46). Related to this, Rawls stated that "Justice is the first virtue of social institution;" this means that a good society is a society that is structured based on the principles of justice (p. 3). In the justice of fairness, he identified the basic structure of society as the main subject of justice. The basic structure of society itself consists of tall social institutions, politics, law and economics. In other words, the basic structure comprises a large institution that manages the social cooperation system. Every basic structure has an individual function, which is to distribute the social burden and benefits to every individual. Everyone involved in this social cooperation must be in a state of freedom and be rational and equal.

An analogy for the basic structure concept and its functions towards relating it with the available social institution can be made. As an example, if the basic structure of a society that Rawls talked about were a political institution, then he would distribute social burden and benefits as "powers" to individuals. Relative to a law institution Rawls would distribute the social burden and benefits as "protection, rights and freedom" for individuals. In this context, individuals are born with different social conditions. Even though different, the justice principles must be manifested; thus, each different individual will always get their principal rights.

In Chapter II titled "The Principle of Justice" (p. 47), Rawls discussed the justice principle. The main idea from "The Principle of Justice" is questioning "what kind of societal organization 
will be chosen if people are in an independent and equal initial position?" This question then brings forth two principles of justice. The two principles are the principle of fair equality and opportunity and the difference principle (p. 57- 67).

Both theories brought Rawls to a justice derivative that is egalitarian. The principle of fair equality and opportunity desires that every individual can obtain equal opportunities; thus, the greatest equal liberty is then formed (p. 171-180). Meanwhile, the difference principle desires that if there is a social and economic difference within a society, then that difference will be regulated in such a way that will give the greatest advantage towards members of society that are less fortunate; therefore, it realizes social justice (p. 65).

Going back to the "Justice as Fairness" concept, the social justice condition can only be achieved if society provides individual freedom that is coupled with a fairness system. Fairness itself is assumed as a competition regulation based on power classification. If fairness were to be given to the maximum, then it can be assumed that poverty will be considered as prosperity in a proper manner (p. 6-8). Justice as fairness is strongly related to the principles that must be enforced in social cooperation that took place within a society. According to Rawls, social cooperation must fulfil three criteria. First, social cooperation is built on rules that general society can accept and not from an authority outside of society. Second, social cooperation must hold on to a fairness concept, which other parties do not dominate. In fair social cooperation, society's freedom must be guaranteed, and freedom will not be sacrificed for anyone else's interests. Third, social cooperation must aim to achieve greater good together (Rawls, 2001, 3-5).

All these concepts expect people to receive fundamental liberties in their lives. Regarding this, Rawls explains that fundamental liberties include political liberty (the right to vote and to hold public office), and freedom of speech and assembly; the liberty of conscience and freedom of thought; freedom of the person, which includes freedom from psychological oppression and physical assault and dismemberment (the integrity of the person); and the right to hold personal property and freedom from arbitrary arrest and seizure as defined by the concept of the rule of law (p. 53).

Next, in Chapter III (p. 102), Rawls explained ways of achieving justice through "The Original Position" theory. Rawls said that the original position was a hypothetical situation in which personal things are behind a veil of ignorance. The veil of ignorance concept is interesting. In short, Rawls would like to convey that if someone wants to act fair, then that person must wear the veil of ignorance. Therefore, a person wearing this veil will go through the process of concealment of self, in which that person has to forget about his or her economic, social and physical status until achieving a social justice position (p. 118).

In Part Two, titled "Institution," Rawls explained the application theories of justice in institutions. The explanation of this matter is not just an illustration but explains how the theory exists in the institution. Rawls discusses how the theory of detail can influence institutions. Rawls also divided his discussion into three chapters. There are, Chapter IV "Equal Liberty," Chapter V "Distributive Shares," and Chapter VI "Duty and Obligation." In Chapter IV, Rawls explains the meaning of equal liberty in his view. Then Rawls simply assume that "any liberty can be explained by a reference to three items: the agents who are free, the restrictions or limitations which they are free from, and what it is that they are free to do or not to do" (p. 177). In this context, institutions have a legal obligation to regulate individual freedom. In Chapter V, Rawls explains about distributive shares by providing a final statement of the two principles of justice for institutions that he previously discussed in Chapter II. In this chapter, Rawls reinforces the formulation of the two principles of justice. The first principle is known as the principal of greatest equal liberty which is "Each person is to have an equal right to the most extensive total system of equal basic liberties 
compatible with a similar system of liberty for all." While the second principle is known as The Difference Principles, which "Social and economic inequalities are to be arranged so that they are both: (a) to the greatest benefit of the least advantaged, consistent with the just savings principle, and (b) attached to offices and positions open to all under conditions of fair equality of opportunity" (p. 266).

In addition to the two principles of justice, both institutions and society have duties and obligations, which Rawls describes in Chapter VI as "Duty and Obligations." In this chapter, Rawls distinguishes between duties and obligations. For him, "duty" is someone's responsibility that must be done voluntarily, namely manifested in the form of "supporting" fair institutions. This means that if the institution has provided justice to society, then society has a "natural duty." to support the institution. In the view of the theory of justice, the most essential natural duty is to support and further just institutions. This duty has two parts: first, we are to comply with and to do our share in just institutions when they exist and apply to us; and second, we are to assist in the establishment of just arrangements when they do not exist, at least when this can be done with little cost to ourselves (p. 293-294). Meanwhile, the "obligations" that Rawls referred to are political obligations that the institution has to keep promises that have been made. In this context, institutions are obligated to provide justice, while society has a "natural duty" to submit to just institutions.

The last parts of this book is Part Three, titled "Ends" describes theories that are more general to clarify the relationship between "Justice as Fairness" and the values of social justice. Part Three is also divided into three chapters, namely, Chapter VII "Goodness as Rationality," Chapter VIII, "The Sense of Justice," and Chapter IX "The Good of Justice” In Chapter VII, Rawls explains the nature of goodness. According to him, a person's goodness is determined by his rationality. In justice as fairness, the concept of right is before that of the good. Rawls makes a distinction between "thin theory" and "full theory of goodness" (p. 348). These two theories are the basis for someone to make a policy and law following the values of social justice. The thin theory aims to guarantee premises about primary values that must exist in the principle of justice. Meanwhile, the full theory of the good is the freedom to use the principles of justice if the thin theory runs and primary values are met.

Linked to goodness as rationality, in Chapter VII, Rawls explained that a well-ordered society would acquire a sense of justice. A well-ordered society will have the awareness that people have a robust rational desire to maintain a sense of justice. To make this happen, Rawls relates it to a psychological perspective. For him, the family is the first institution of moral education. The basic structure of a well-ordered society is formed from a family that has instilled a sense of justice in their children (p. 405). Sense of justice must be formed early and gradually. In the first stage, parents show love for their children through the care they provide. This will form a reciprocal relationship where the children will also love their parents. Second, children will trust their parents and their surroundings. Third, the love and trust that has grown will develop various skills in children. Gradually, children will gain self-confidence. Fourth, the child has a close bond with parents so that it forms a sense of guilt known as "authority guilt," which is a proto-moral sentiment in which a child will feel guilty if he or she does not obey his parents' orders. At the proto-moral stage, children will be able to evaluate the good and bad of an action. This moral formation will carry over until a child becomes an adult and mingles in society (p. 405-413). The reciprocal relationship between parents and children will be carried over to the context of the state. Community members will obey the rules if the government gives compassion to its people. It is assumed that family members who already have a sense of justice will undoubtedly be fair in everyday life, including if one day they become a stakeholder in an institution. 
The last chapter IX, titled "The Good of Justice." explained cases of social envy that may occur in society. Usually, social envy is born out of jealousy over other people's luck. Rawls explains that envy arises due to three conditions: 1) the psychological condition of people who are not sure of their values or abilities; 2) visible gaps in the social structure and lifestyle of the community; and 3) unfavorable social position in society. For these three conditions, social institutions are the base instigating cause (p. 468). Furthermore, Rawls provides a solution so that institutions/governments carry out social arrangements so that social envy does not occur excessively. Arrangements can be made by using the difference principle of justice, as mentioned in Chapter II of this book.

In all the parts and chapters that Rawls wrote, the conclusion can be made that the perspective of Rawls has contributed theoretically to the development of contemporary political philosophy and moral philosophy. Currently, the theory of justice has succeeded in becoming a foundation for academics, politicians and stakeholders to explain or make a policy related to distributive shares. The theory put forward in this book can also be the basis for the scientific development of political philosophy. Thus, the theory of Rawls is not only useful for explaining justice in an economic and social context. Rawls theory can be developed to analyze instances of racial injustice that has been an issue and widely talked around the world.

\section{Justice Theory and Ethnicity}

Ethnicity can be defined as a human community that has a name, is related to one motherland and has a common ancestral myth, shared memories, one or several common cultural elements, and certain solidarity among its elites (Smith, 2001,15). Therefore, ethnic identity can be a combination of ethnic, religious, gender, class and other layers all of which refer to the same person either in self-definition or as defined by others (Alubo, 2009, 1-2; Vanhanen, 2012).

Theoretically, ethnicity contains two perspectives inside. They are the primordialist and sociological perspectives. The primordialist perspective assumes identity as a group, where something natural within it includes relationships based on blood, race, language, religion, territory and others. This relationship is very binding and believed by a primordialist to be an ethnic identity (Geertz, 1973, 250). Conversely, socio-biology refers to behavior. As Berghe (1981) explained in his book, titled The Ethnic Phenomenon, sociobiological relates to human biology itself, that is expressed in nepotistic behavior, thus creating kinship. This means relations between ethnicities will happen if the two have kinship and cooperation and how close the two as individuals.

Even though the two are different, these two perspectives also have similarities in the ethnic relation context. This closeness and kinship relationship, whether primordialist or sociological, will be a cornerstone for one ethnic group to unite. In a plural country, ethnicity has an essential role in keeping a country stable. A leader must distribute justice for all ethnic groups to prevent vertical and horizontal conflicts from happening.

However, injustice ethnic issues have become problems that many countries around the world have faced (Mohammadzadeh, 2010; Wolff, 2007). Usually, bad policies lead to the death of millions of people, destructive action, separatism, discrimination, terrorism, and disintegrations of many countries. Ethnicities that are left out by the country's social and political policies of a country ultimately ask for independence and self-determination. For example, consider the ethnic Uyghur-China conflict. As an ethnic minority in China, ethnic Uyghur have faced discrimination of rights such as violates of freedom of religion, and the government backs ethnic Han, who dominates almost all aspect of production in Xinjiang (Clarke, 2015; Fuller \& Starr, 2011; Rayila, 2011). The ethnic Kurdish have fought for their autonomy in Iraq and Turkey (Celik, 2012; Duffy, 
2003; Rogg \& Rimscha, 2007). Conflict with injustice background has also happened in Ethiopia in which the Tigray People's Liberation Front (TPLF) has fought against the centralized government of Ethiopia (Abbink, 2006; Allaro, 2019; Berhe, 2008). Sri Lanka also faced conflicts between ethnic Sinhala and ethnic Tamil. Here, the government is dominated by ethnic Sinhala, which has committed all kinds of injustice towards ethnic Tamil. This triggered the establishment of a freedom group known as Liberation Tigers of Tamil Eelam (LTTE) that surfaced in 1976 (Balasuriya, 2009; De Votta, 2003; Höglund, 2005; Yass, 2014). Racial injustice also happened in the United States. African-Americans faced injustice and discrimination in many aspects, such as education, workforce, healthcare, and housing. This racial inequality has become historically corrosive in American society (American Sociological Association, 2007; Shedd \& Hagan, 2006). In Indonesia, the inequality of the central government in distributing wealth brought forth three ethnic movements: Republic of South Moluccas (RMS), Papua Freedom Organization (OPM), and Aceh Free Movement (GAM). All of these three movements are ethnic-based and want independence by separating from Indonesia (Aguswandi, 2008; Brown, 2005; Sari, 2018; Sari et al., 2019; Schulze, 2004; Smith, 2002; Thaib, 2017).

In the several cases mentioned above, ethnic conflicts happened not just because of ethnic difference alone. There are other more prominent reasons in the form of injustice or inequality that governments have created towards certain ethnicities over the years. In this context, Varshney (2003) explained that ethnicity is seen as an instrumental aspect. Because the government cannot be just, then ethnicity became the instrument for a mobilization strategy to fight against that injustice.

In most ethnic conflict cases, the central government has shaped the injustice frame. Thus, if some scholars are interested in analyzing that injustice, the John Rawls justice theory can be used. In analyzing injustice, researchers can use four basic questions that were mentioned by Rawls to map out research questions that are faced with and look for answers to those problems scientifically using Rawls' theory. The four questions are: what are the key areas of justice? What problems appear in justice? What are the justice principles that must be fulfilled? and how to achieve justice?

When researchers are faced with ethnic problems about injustice, the first and second question about "what are key areas of justice" and "what problems appear in justice" can help researchers to identify "in which institution injustice appears, what are the problems and what effects it has on individuals?" Researchers can use the key areas of justice to look at these justice problems comprehensively. These include problems that appear in every key area of justice that comprise the basic structure of society, the entire institution: social, politic, law and economics. Every basic structure has its function specified, which is to distribute burden and social benefits for individuals (p. 400).

For example, in GAM in Aceh, Indonesia, the justice key areas having problems have occurred place in politics and economics institutions. The exploitation of crude oil by the Indonesian government in Aceh in the 1970s did not provide any economic benefits to the ethnic Acehnese. The benefits obtained were not distributed equally; therefore, Aceh experienced massive poverty, which became the trigger for the creation of AFM (Sari, 2018).

Concerning base question number three, which was about the justice principles that must be fulfilled (p. 52-65), Rawls offered two principles. They are Principle of Fair Equality and the Difference Principle. Therefore, researchers can use the two principles in analyzing how far a government has gone in developing the greatest equal liberty. The Principle of Fair Equality of Opportunity require the government to provide equal opportunities; thus, individual rights are fulfilled. In the case of Uyghurs, the Principle of Fair Equality of opportunity is not fulfilled 
because this ethnic minority cannot exercise religious rights. In the case of racial conflict discrimination of African-Americans, disparities exist in social rights. Researchers can use the second principle, the difference principle, to explain the social differences that arise between ethnicities within a country, which the government should manage to provide a fair system within the state.

Next, the fourth base question about "how to achieve justice can be an analysis tool for researchers to find a solution about what should the government do to achieve and minimize potential ethnic conflict. Rawls offered two ways, which are "the original position" and "Veil of Ignorance." Regarding these two concepts, social justice can be achieved if the government can reach its original position by wearing a veil of ignorance. To do this, everyone must ensure that all personal things are behind the veil of ignorance, and every ethnicity must forget its economic, social, and physical status. Then assumed, when the veil of ignorance is successfully applied, everyone will be committed to the principles of social and political justice. Thus, there are no views regarding the ethnic majority or the ethnic minority, and all ethnicities are considered on equal footing in the eyes of the country.

\section{Critics, Weaknesses and Strengths of Rawls' Works}

A Theory of Justice has some strengths and weaknesses. The strength of Rawls' work rests in its ability to integrate morality aspects with justice theory. Although discussions exist in every section, part three, chapter VIII about the sense of justice (p. 397-422) is particularly important. Rawls said that to achieve social justice, every individual must perform moral sacrifice and commit to wearing the "veil of ignorance." Through his writing, Rawls was able to bring the readers to the "state of nature" period, the place where the classic philosophers Locke and Rousseau constructed social contract in the society. The classical frame of thinking depicted that the human state of nature was evil and anarchist, and only the strong survived.

However, when humans became exhausted with the anarchist lifestyle, they agreed on a social contract by surrendering their personal sovereignty to a government entity (Bakalar, 2018). The contract that was made between the government and society was quite minimalist. Therefore, the government only provided a certain level of physical security. Interestingly, Rawls found that the "state of nature" condition was not feasible to explain justice, so he modified it and established a new justice concept in the form of "justice as fairness," "the original position," and "veil of ignorance". Another strength is that A Theory of Justice can serve a guideline for governments in creating social policies around the world, implicating in justice, including reducing ethnic conflicts that may arise in a country. Another strength lies in Rawls's ability to write his arguments clearly and accurately so that Rawls's ideas can be used across disciplines.

Regardless of its strengths, the concepts of the veil of ignorance and the original position are challenging to achieve. Indeed, Nozick (1974) considered it a utopian view. Sen (2002) stated that Rawls wanted plenary justice, but a more grass-roots approach was needed to realize justice. Okin (1989), a feminist, argued that a theory of justice could not explain justice in the context of traditional family and gender. Okin (1989) believed that Rawls failed to explain injustice in patriarchal social relations and the gendered division of labor, especially in the household. Despite these criticisms, Rawls' philosophical theories remain relevant to an analysis of injustice in the contemporary world. 


\section{References}

Abbink, J. (2006). Ethnicity and conflict generation in Ethiopia: Some problems and prospects of ethno-regional federalism. Journal of Contemporary African Studies, 24(3). 389-413. https://doi.org/10.1080/02589000600976729

Aguswandi, W. Z. (2008). From politics to arms to politics Again: The transition of Gerakan Acheh Merdeka (Free Aceh Movement-GAM). Berghof Research Center for Constructive Conflict Management. Berlin, Germany.

Allaro, H. B. (2019). The effect of Tigray People's Liberation Front ethnic federalism on Ethiopian democratic uncertainty and political violence. Journal of International Politics, 1(3), 7688.

Alubo, O. (2009). Citizenship and identity politics in Nigeria. In Conference Proceedings on Citizenship and Identity Politics in Nigeria, Lagos (pp.1-4). CLEEN Foundation,

American Sociological Association. (2007). Race, ethnicity, and the criminal justice system. ASA Series on How Race and Ethnicity Matter. Department of Research and Development.

Bakalar, B. (2018). Book Review: Justice on both sides: Transforming education through restorative justice. American Journal of Qualitative Research, 2(2), 145-149.

Balasuriya, M. (2009). The rise and fall of the LTTE. Asian Network on Conflict Research.

Berghe, V.D. (1981). The ethnic phenomenon. Elsevier.

Berhe, A. (2008). A political history of the Tigray People's Liberation Front (1975-1991): Revolt, ideology and mobilization in Ethiopia. Vrije Universiteit. http://www.harep.org/Africa/7219.pdf

Brown, G. (2005). Horizontal inequalities, ethnic separatism and violent conflict: The case of Aceh, Indonesia. Human Development Report Office. UNDP.

Celik, A. B. (2012). Ethnopolitical conflict in Turkey: From the denial of Kurds to peaceful coexistence? In D. Landis \& R.D. Albert (Eds.), Handbook of ethnic conflict: International perspectives, International and Cultural Psychology (pp. 241-260). Springer.

Clarke, M. (2015). China and the Uyghurs: The "Palestinization" of Xinjiang? Middle East Policy 22, 127-146. https://doi.org/10.1111/mepo.12148

De Votta, N. (2003). Sri Lanka's Political Decay: Analyzing the October 2000 and December 2001 parliamentary elections. Commonwealth \& Comparative Politics. 41(2), 115-142. https://doi.org/10.1080/14662040412331310121

Duffy T. M. (2003). The geography of ethnic violence: Identity, interests, and the indivisibility of territory. Princeton University Press.

Fuller, G.E., \& Starr, S.F. (2011). The Xinjiang Problem. Central Asia-Caucasus Institute. John Hopkins University. https://www.files.ethz.ch/isn/30301/01_Xinjiang_Problem.pdf

Geertz, C. (1973). The interpretation of cultures. Free Press.

Höglund, K. (2005). Violence and the peace process in Sri Lanka. Civil Wars, 7(2), 156-170. https://doi.org/10.1080/13698280500422843

Nozick, R. (1974). Anarchy, state, and utopia. Blackwell Publishers Ltd.

Mohammadzadeh, H. (2010) The type of ethnically among Kurdish people [Doctoral dissertation, Allame Tababai University].

Okin, S.M. (1989). Justice, gender, and the family. Basic Books, Inc.

Rawls, J. (1971). A theory of justice. Harvard University Press.

Rawls, J. (1993). Political liberalism. Columbia University Press.

Rawls, J. (1999). The law of people. Harvard University Press.

Rawls, J. (1999). A theory of justice: Revised edition. Harvard University Press. 
Rawls, J. (2001). Justice as fairness: A restatement. Harvard University Press.

Rayila, M. (2011). The pain of a nation: The invisibility of Uyghurs in China proper. The Equal Rights Review, 6, 44-57. https://www.upr-info.org/followup/assessments/session17/china/ China-BAI-annex.pdf

Rogg, I. \& Rimscha, H. (2007). The Kurds as parties to and victims of conflicts in Iraq. International Review of the Red Cross, 89(868), 823-842. https://doi.org/ $10.1017 / \mathrm{S} 1816383108000143$

Sari, C.M.A. (2018). The imagined community of Indonesia: Pertentangan Nasionalisme Indonesia Vs Etnonasionalisme Bangsa Aceh Dalam Gerakan Aceh Merdeka (GAM). Al-Ijtima i: International Journal of Government and Social Science, 3(2), 131-152. https://journal.arraniry.ac.id/index.php/jai/article/view/442/229

Sari, C.M.A., Hasan, H., Syahbandir, M., \& Efendi, E, (2019). The internalisation process and pattern on ideology ethnonationalism from five leaders of the Free Aceh Movement to their children. International Journal of Innovation, Creativity and Change. 7(8),90-104. https://ijicc.net/images/vol7iss8/7805_Sari_2019_E_R.pdf

Schulze, K. E. (2004). The Free Aceh Movement (GAM): Anatomy of a separatist organization. East-West Center Washington. https://scholarspace.manoa.hawaii.edu/bitstream/handle/ 10125/3514/PS002.pdf?sequence $=1$

Sen, A, K. (2002). Open and closed impartiality. The Journal of Philosophy, 99(9), 445-469.

Shedd, C, \& Hagan, J. (2006). Toward a developmental and comparative conflict theory of race, ethnicity, and perceptions of criminal injustice. In The many colors of crime: Inequalities of race, ethnicity, and crime in America (pp, 313-333), NYU Press. http://web.stanford.edu/ mldauber/workshop/Shedd_HaganAugust2006.pdf

Smith, A. D. (2001). Nationalism: Theory, ideology, history. Polity Press.

Smith, A. L. (2002). Aceh: Democratic times, authoritarian solutions. New Zealand Journal of Asian Studies 4(2), 68-89. http://www.nzasia.org.nz/downloads/NZJAS-Dec02/Smith.pdf

Thaib, L. (2017) Aceh: The case for political integration. Sejarah: Journal of the Department of History, 13(13), 223-244.

Vanhanen, T. (2012). Ethnic conflicts: Their biological roots in ethnic nepotism. Ulster Institute for Social Research.

Varshney, A. (2003), Nationalism, ethnic conflict, and rationality. Apsanet, 1(1), 85-99. https://doi.org/10.1017/S1537592703000069

Wolff, S. (2007). Ethnic conflict: A global perspective. Oxford University Press.

Yass, S. (2014). Sri Lanka and the Tamil Tigers: Conflict and legitimacy. Military and Strategic Affairs, 6(2), 65-82.

\section{Notes on Contributors}

Cut Maya Aprita Sari, S.Sos., M.Soc.Sc has served as a lecturer and researcher in Political Science Department of Universitas Syiah Kuala, Aceh - Indonesia since 2013. She finished her undergraduate studies in the Department of Political Science, Faculty of Social Science and Humanities, University of North Sumatera (2011). She received her Master degree at Political Science Department in National University of Malaysia (2013). Currently, she is a PhD Student at the Institute of Ethnic Studies in the National University of Malaysia. Her research interests are Political Theory and Philosophy, Conflict and Peace Studies, Ethnicity, Identity and Nationalism. 